\title{
EDUKASI ONLINE TERHADAP TINGKAT PENGETAHUAN MENJAGA ORAL HYGIENE SELAMA PANDEMI COVID-19
}

\author{
Fateh Hayati Iatassomi ${ }^{1}$,Suci Erawati ${ }^{2}$, Molek $^{3}$ \\ Fakultas Kedokteran Gigi, Universitas Prima Indonesia \\ Email:yatasomi8@gmail.com1, esuci64@gmail.com2,_drg.molek@yahoo.com3
}

\begin{abstract}
Oral health and hygiene reflect a person's health condition entirely. High prevalence on COVID-19 cases are likely to connect with lack of oral hygiene maintenance. Education is one of knowledge changes towards an educative method with well-planned, systematic, and directed activity with active participation from person, group, or community to solve the problems, considering economic and cultural backgrounds. Oral hygiene maintenance during COVID-19 pandemic is important because it can help us to improve our immunity system. The purpose of this research is to determine the online education effect towards oral hygiene maintenance level during COVID-19 pandemic. This research was conducted by cross sectional analysis. Samples were collected with accidental sampling technique and data were collected by questionnaires. The results of this research with paired $t$ test statistical analysis showed $p$ value $=0,001(p<0,05)$, which means that there are significant differences between oral and dental hygiene behavior during COVID-19 pandemic before and after online education. From this research, it stated that there were significant differences in online education effect towards oral hygiene maintenance knowledge changes during COVID-19 pandemic.
\end{abstract}

Keywords: online education; oral hygiene; covid-19 pandemic.

\begin{abstract}
ABSTRAK
Oral Hygiene yang baik menunjukkan status kesehatan keseluruhan individu. Tingginya kasus covid-19 kemungkinan ada hubungannya dengan kurang pengetahuan tentang menjaga oral hygiene. Mengedukasi merupakan salah satu perubahan pengetahuan manusia melalui pendekatan edukatif dengan mengikuti rangkaian kegiatan yang terencana, sistematik, terarah dengan peran aktif kelompok, individu, ataupun masyarakat, untuk menyelesaikan masalah dengan memperhitungkan faktor budaya dan ekonomi sosial Menjaga oral hygiene di masa pandemi covid-19 juga tidak kalah penting, karena dengan menjaga oral hygiene dapat menyempurnakan sistem kekebalan tubuh.Tujuan penelitian ini apakah adanya pengaruh edukasi online terhadap tingkat pengetahuan menjaga oral hygiene selama pandemi covid-19. Metode penelitian dilakukan dengan analytic cross sectional. Pengumpulan sampel dilakukan dengan teknik accidental sampling. Data menggunakan kuesioner. Hasil penelitian ini diperoleh uji statistik paired $t$ test diperoleh $\mathrm{p}$ value $=0,001(\mathrm{p}<0,05)$ yang berarti bahwa ada perbedaan secara signifikan pengetahuan menjaga oral hygiene di masa pandemi covid-19 sebelum dan sesudah edukasi online. Hasil penelitian dapat dinyatakan bahwa ada pengaruh edukasi online terhadap perubahan pengetahuan menjaga oral hygiene terhadap perubahan pengetahuan menjaga oral hygiene di masa pandemi covid-19.
\end{abstract}

Kata kunci: edukasi online; oral hygiene; pandemi covid-19.

\section{INTRODUCTION}

Understanding oral hygiene impacts the importance of maintaining oral and dental hygiene. Good oral hygiene reflects a person's health condition entirely. Healthcare is one of the factors that can affect individual oral and dental hygiene. This can play an important role to determine status of oral and dental health. ${ }^{(1)}$ Dental health includes all knowledge regarding dental maintenance. Good oral hygiene is integrated with good body health entirely. ${ }^{(2)}$

Maintaining oral and dental hygiene can increase someone's ability to speak and smile, so they can communicate better. Normal bacteria that live in the oral cavity consist of Streptococcus mutans, Lactobacillus sp, and Staphylococcus sp. But those bacteria could turn into pathogensbecause of predisposing factors that were related to oral hygiene. Food leftovers that are remaining in the oral cavity will be decomposed, producing acid components that are attached to teeth email surfaces. This can cause demineralization that can lead into caries.

Majority of Indonesia citizens had an understanding about the proper way to brush teeth and the frequency to brush their teeth, howeveronly $28 \%$ people that do those habits properly, which are twice per day, after breakfast and before going to bed. Based on the level education, people 
with higher education level understand better than the lower education according to their brushing teeth habit $(99,2 \%)$ with the right frequency of brushing teeth around $6,2 \%$. From this data, Basic Health Research of Indonesia stated that people who are suffering with dental pain/caries because of lack of oral hygiene were $45,3 \%$, followed by swollen gums and abscess around $14 \%$. $^{(3)}$

Education is one of knowledge changes towards an educative method with well-planned, systematic, and directed activity with active participation from person, group, or community to solve the problems, considering economic and cultural backgrounds. ${ }^{(4)}$ With this education method, it involves a lot of sense that affects the success of dental and oral knowledge. ${ }^{(5)}$

Maintaining oral hygiene during COVID19 pandemic is important for us, because it can affect our immunity system. Healthy oral cavitycan defend our immunity system from various kinds of bacteria and viruses. During COVID-19 pandemic, maintaining oral and dental hygiene are important to prevent any interference or damage around oral cavity soft tissue.

The recent type of Coronavirus, SarsCoV2, can trigger COVID-19 disease with different types of symptoms that invades human respiratory tract, like cold, cough, to severe cases like MERS (Middle East Respiratory Syndrome and SARS (Severe Acute Respiratory Syndrome). According to WHO, Coronavirus can affect human and animal health. ${ }^{(6)}$ SarsCoV-2 can spread among people isthe main reason of COVID-19 aggressive widespread. SarsCoV-2 can spread to other people through droplets when an infected person coughs, sneezes or talks. This virus can spread through aerosol from a nebulizer approximately for three hours. Other risk factors that infected this disease are close contact or living with COVID-19 patients. ${ }^{(7)}$

Common COVID-19 symptoms in the respiratory tract system are fever, voluminous cough, sneeze, difficulty to breath, limp, headache, nausea/vomit, nasal congestion, diarrhea, abdominal pain. Fever between $38,1-39^{\circ} \mathrm{C}$ with incubation process around 3-14 days. The majority of virus loads are located in nasopharyngeal and oropharyngeal. Saliva contains the highest COVID-

19 viral load, around 1,2 x 108 copy/ml. ${ }^{(8)}$

Dental and oral health issues are still relatable in Indonesia because dental caries and periodontal disease prevalence cases are still around $80 \%$ from the entire population. ${ }^{(3)}$ This disease could happen because of poor oral and dental maintenance. According to Health Ministry Policy article 89 in 2015 about Dental and Oral Endeavor, dental and oral health is a condition when every hard and soft tissue and all elements that involved in the oral cavity are in the goodcondition, which allow the person to eat, talk and interact socially without any dysfunction, aesthetic problem and discomfort because of disease, occlusion abnormalities and teeth lose, so the person could live productively, either socially or economically.

However, all those problems could be avoided if we brush teeth regularly minimal twice per day, morning after breakfast and night before going to bed, also don't forget to clean the tongue, gargle with mouthwash after brush teeth, use dental floss to clean interdental area, and change damaged toothbrush, stop smoking habit, limit sweet foods and beverages, add a lot of high fiber fruits and vegetables into regular diet, and consume mineral water eight glass per day.

\section{METHOD}

This research was conducted by cross sectional analysis with questionnaires as a measurement. Questionnaires of this research consisted of oral hygiene knowledge during COVID-19 pandemic situation. Sample of this research were PT. Perta Arun Gas complex in Lhokseumawe residents which were 40-50 yearsold that willing to fill this questionnaire and informed consent.

Sample was chosen by accidental sampling technique. This technique took participants from one community that fit into the researcher's topic. There are 15 questions to measure oral and dental rehabilitation knowledge level and 15 questions to measure oral and dental behavior. Questionnaires were given to the PT. Perta Arun Gas complex in Lhokseumawe, Aceh residents who were 40-50 years old. There were 50 participants in this research.

Material and tools that were used for this research were gadget, research information, informed consent questionnaire that had already been validated before. Data was collected and presented with several tables. This research was conducted in the PT. Perta Arun Gas resident to determine the effect of online education to oral and dental knowledge level and rehabilitation during COVID-19 pandemic. The data was analyzed statistically by t-test dependent.

\section{RESULT}

According to the participants' age, the majority of participants with the age of 40-43 years old were 27 people (54\%), 44-47 years old were 15 people $(30 \%)$, and $48-50$ years old were 8 people $(16 \%)$. Based on gender, the participants were dominated by male with a total of 31 people $(62 \%)$, and female participants with a total of 19 people (38\%). Research results based on the participants' age and gender characteristic shown in Table 3.1 
Table 3.1 Participants characteristic

\begin{tabular}{lccc}
\hline Characteristic & N & \% \\
\hline Age & & & \\
& $40-43$ & 27 & 54 \\
& $44-47$ & 15 & 30 \\
& $48-50$ & 8 & 16 \\
\hline Gender & Total & 50 & 100 \\
& Male & 31 & 62 \\
& Female & 19 & 38 \\
\hline
\end{tabular}

Research results showed the average score of oral hygiene knowledge level during pandemic before online education was $23,48 \pm 4,36$ and after online education was $25,32 \pm 3,17$.
The average score of oral hygiene knowledge level during pandemic before and after online education shown in Table 3.2 .

Table 3.2 Average score of oral hygiene knowledge level during COVID-19 pandemic before and after online education

\begin{tabular}{ccc}
\hline Knowledge & $\bar{x}$ & SD \\
\hline Before & 23,48 & 4,36 \\
After & 25,32 & 3,17 \\
\hline
\end{tabular}

Results showed that the average score of oral hygiene knowledge level during COVID-19 pandemic before online education was $23,48 \pm 4,36$ dan after online education was $25,32 \pm 3,17$ with the before and after score difference was 1,84 $\pm 1,19$. Paired t-test statistical analysis showed that the $\mathrm{p}$ value $=0,001(p<0,05)$, which means that there was a significant difference on oral hygiene knowledge level during COVID-19 pandemic before and after online education. Results of online education effect towards oral hygiene knowledge level during COVID-19 pandemic shown in Table 3.3

Table 3.3 Online education effect towards oral hygiene knowledge level change during COVID-19 pandemic.

\begin{tabular}{ccccc}
\hline Knowledge & ${ }^{-} \boldsymbol{x} \pm$ SD & Mean diff & p value & Description \\
\hline Before & $23,48 \pm 4,36$ & & 0,001 & $\begin{array}{l}\text { There were } \\
\text { significant } \\
\text { difference }\end{array}$ \\
After & $25,32 \pm 3,17$ & $1,84 \pm 1,19$ & 0 & \\
\hline
\end{tabular}

\section{DISCUSSION}

Oral hygiene is important for body health and welfare generally and affects the quality of life, including mastication, articulation andconfidence. ${ }^{(9)}$ Maintaining oral hygiene during COVID-19 is important, because maintaining oral hygiene could affect the immune system to fightany kinds of bacteria and viruses. Maintaining oral hygiene during COVID-19 pandemic is important to prevent any interference or damage around the oral cavity, including teeth, hard and soft tissue. Pretest questionnaire data that were collected from the PT. Perta Arun Gas complex residents showed that there is still an effort that residents had done to maintain their oral hygiene during COVID-19 pandemic, but there are several mistakes that they have done, like making a dental visit but not for emergency cases. This shouldn't be done during a pandemic because dentists still have the higher risk of COVID-19 infection, besides medical workers who work for COVID-19 patients. ${ }^{(10)}$

Humans are one of the main sources of COVID-19 virus widespread which occurs through droplets when coughing or sneezing. Respiratory tract cells on the alveoli layer could be infected by COVID-19. This virus attaches to the cells and makes ways to bond with alveoli cells. ${ }^{(7)}$ Successful oral and dental hygiene will be reviewed from public awareness, environment, and health service and treatment. Oral and dental hygiene results come from a better understanding about oraldisease, such as gingival inflammation (gingivitis) and calculus (accumulation of dental plaque). Another method that can be used to maintain public oral hygiene during COVID-19 pandemic is online education.

According to research data from 50 residents live in PT. Perta Arun Gas complex residence showed that the majority of participant 
ages in the range of 40-43 years old with a total of 27 people $(54 \%), 44-47$ years old with a total of 15 people $(30 \%)$, and 48-50 years old with a total of 8 people (16\%). It showed that residents from age 4043 years old had the highest interest that affects knowledge level and curiosity to improve quality of life. Based on the gender, participants were dominated by male with a total of 31 residents (62\%), and female participants with a total of 19 residents $(38 \%)$, because most of the workers are male workers that live in PT. Perta Arun Gas complex residence.

The average score of oral hygiene knowledge during COVID-19 pandemic before online education was $23,48 \pm 4,36$ and after online education were $25,32 \pm 3,17$ with average difference scores was $1,84 \pm 1,19$. Analysis statistics paired t-test results showed $\mathrm{p}$ value $=0,001$ $(\mathrm{p}<0,05)$, which means there are significant differences towards oral hygiene during COVID-19 pandemic before and after online education. From this research, it showed that there are online education effects towards oral hygiene knowledge changes during COVID-19 pandemic.

\section{CONCLUSION}

1. Average score of oral hygiene knowledge during COVID-19 pandemic before online education was $23,48 \pm 4,36$.

2. Average score of oral hygiene knowledge during COVID-19 pandemic after online education was $25,32 \pm 3,17$.

3. Based from the research, online education could increase oral hygiene knowledge change in PT. Perta Arun Gas complex residents with average difference sore before and after online education was $1,84 \pm 1,19$ and $p$ value $=0,001 \quad(p<0,05)$, which means that there were any significant difference with oral hygiene knowledge before and after online education during COVID-19 pandemic.

\section{SUGGESTION}

1. We suggest that citizens need to improve oral hygiene to prevent various kinds of oral and dental disease.

2. We suggest that medical workers and teachers should use online education as an alternative method, especially to maintain their oral hygiene during COVID-19 pandemic.

\section{REFERENCE}

1. Narulita L., Diansari V., Sungkar S. Oral Hygiene Index Simplified (OHIS) pada
Murid Kelas IV SD Negri 24 Kuta Alam. Journal Caninus Dentistry. 2016; I(4):6-8.

2. Pintatauli, S dkk. 2016. Мепијu GigiSehat: Pencegahan dan Pemeliharaannya.Medan: USU Press.

3. Puspadatin. Kemkes (2019). Situasi Kesehatan Gigi dan Mulut. Infodatin gigi 2018. Jakarta: Kementrian Kesehatan.

4. Genjir, I.N, Kencana, I.G.S, Artawa, I.M.B, Suanda, I.W, 2020, Implementasi Proses Pembelajaran Dalam Penyuluhan Kesehatan Bagi Tenaga Kesehatan. Malang: MNC.

5. Tandilangi, M., Mintjelungan, C.,Wowor, V.N.S. 2016. Efektivitas dental Helth Education Dengan Media Animasi Kartun Terhadap Perubahan Perilaku Kesehatan Gigi dan Mulut Siswa SD Advent 02 Sario Manado. Jurnal e-GiGi (eG), 4(2), hal. 106 $-110$.

6. Infeksimerging. Kemkes. 2020. Informasi Tentang Virus Corona (Nover Corona Virus). Jakarta: Promkes Kementerian Kesehatan RI dan Perhimpunan Dokter Paru Indonesia.

7. Susilo, A dkk. 2020. Coronavirus Disease 2019. Penyakit Dalam Indonesia Vol.7. No 1(3). p.45-67.

8. Bayley J.K, Sunkaraneni V.S., Challacombe S.J. 2020. The Use of Providone Iodine Nasal Spray and Mouthwash During the Current COVID19 Pandemic May Reduce Cross Infection and Protect Healthcare Workers.

9. Putri, M. H., Nurjannah, N. 2015. Ilmu Pencegahan Jaringan dan Pendukung Gigi. EGC: Jakarta.

10. Kemenkes. 2020. Riset Kesehatan Dasar; RISKESDAS. Jakarta: Balitbang Kemenkes RI. 